\title{
К истории 8-й дивизии народного ополчения
}

Олег Бакулин

Автор рассматривает историю 8-й дивизии народного ополчения Краснопресненского района города Москвы, в рядах которой, наравне с другими добровольцами, сражались студенты, аспиранты, преподаватели и сотрудники МГУ имени М.В. Ломоносова.

Особое внимание уделяется деятельности поискового отряда «Вымпел - поиск МГУ», состоящего преимущественно из студентов Московского государственного университета и занимающегося поисками пропавших без вести осенью 1941 г. бойцов и командиров 8-й дивизии.

Ключевые слова: народное ополчение, 8-я дивизия, МГУ, история, военная археология.
@ Бакулин Олег Александрович кандидат исторических наук, доцент, заведующий кафедрой фотожурналистики и технологий СМИ факультета журналистики МГУ имени М.В. Ломоносова (г. Москва, Россия), obakulin@yandex.ru
Истории народного ополчения в годы Великой Отечественной войны посвящено немало работ советских/российских исследователей. Вместе с тем говорить, что эта тема досконально изучена, было бы неверно. Наглядный пример - история 8-й дивизии народного ополчения Краснопресненского района города Москвы, которая частично была сформирована из студентов, аспирантов, преподавателей и сотрудников МГУ. В частности, анализ имеющихся источников (прежде всего, мемуарного характера) не позволяет доподлинно реконструировать события начала октября 1941 г., связанные с участием дивизии в боях под Ельней, узнать о судьбе многих пропавших без вести краснопресненцев. Отчасти этот пробел могут восполнить данные военной археологии, крайне редко оказывающиеся в поле зрения исследователей народного ополчения. Истории, а также проблеме поиска пропавших без вести осенью 1941 г. бойцов и командиров 8-й дивизии, посвящен данный обзор.

\section{8-я Краснопресненская: вехи пути}

В связи с крайне тяжелой ситуацией на фронте 4 июля 1941 г. Государственным комитетом обороны (ГКО) было принято постановление «О добровольной мобилизации 


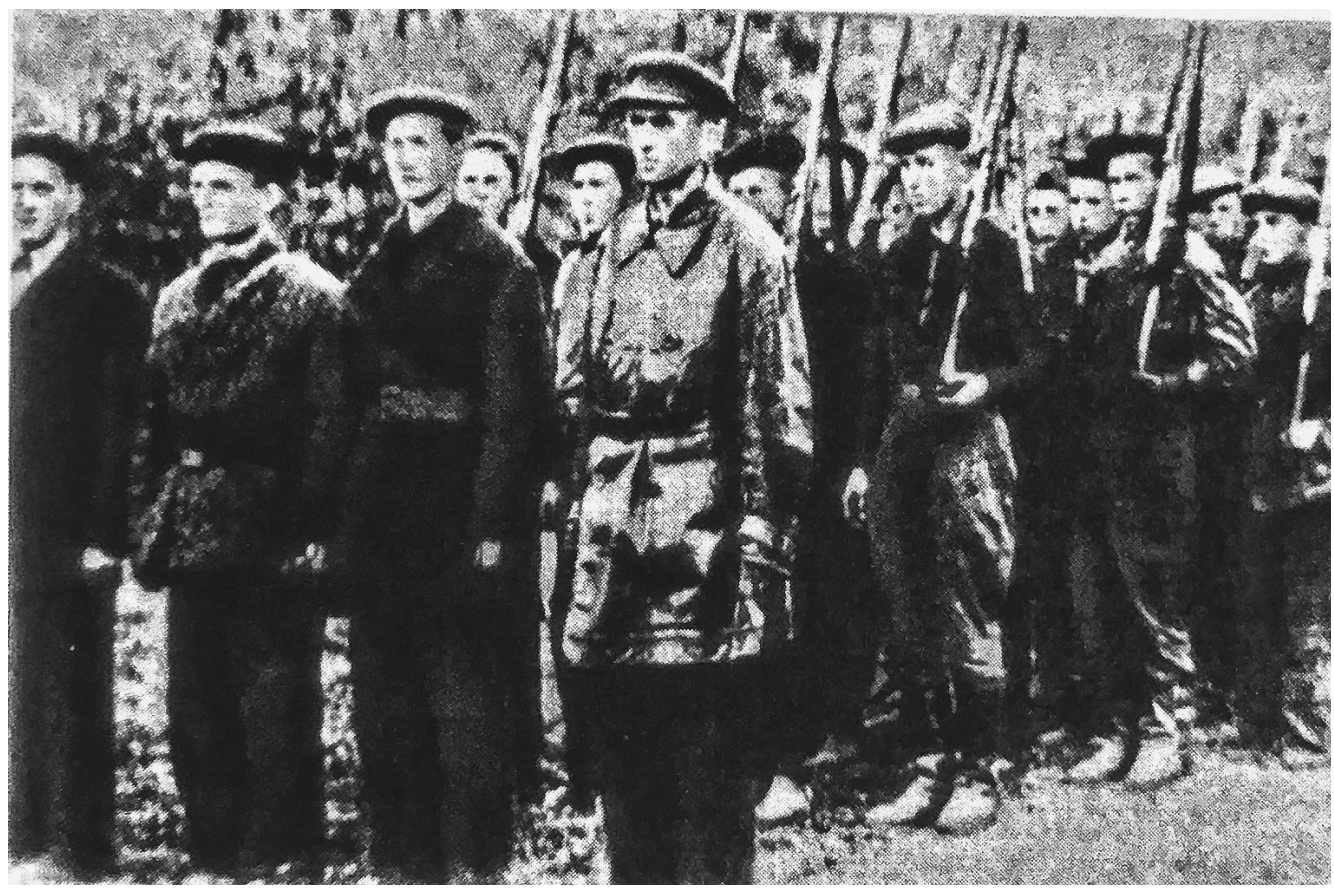

Ополченцы Красной Пресни. Первые дни формирования дивизии Источник: Пошеманский Ю.М. Солдаты Красной Пресни

трудящихся Москвы и Московской области в дивизии народного ополчения»1. Ополчение создавалось из граждан, не подлежавших призыву в возрасте от 17 до 55 лет. Уже через несколько дней в городе было сформировано 12 дивизий. Многие студенты, аспиранты, преподаватели и сотрудники МГУ записались добровольцами в 8-ю дивизию народного ополчения Краснопресненского района города Москвы (далее - 8-я ДНО), на территории которого находился Московский государственный университет².

По данным за июль 1941 г., при комплектовании 8-й ДНО Московский универ- - называет (со ссылкой на подсчеты Пресситет «дал более 1000 добровольцев»з. ненского военкомата, основанные на анаВ ряде работ можно встретить уточненные лизе книг поименного учета личного соданные. Так, в первом издании коллектив- става дивизии) иные цифры: примерно ного труда «Московский университет в Ве- 1600-1700 человек. Более точные данные, ликой Отечественной войне» речь идет о по его мнению, сегодня назвать сложно, т.к. том, что в течение первой недели созда- часть документов в 1990 гг. была безвозвратния дивизии в ряды народного ополчения но утрачена7. 
Из студентов, аспирантов, преподавателей и сотрудников Московского университета был сформирован 975-й артиллерийский полк, а также полностью укомплектован политсостав 8-й ДНО. При формировании дивизии учитывалась гражданская специальность ополченцев: «Например, саперная рота комплектовалась из студентов геолого-почвенного факультета МГУ и студентов Геологоразведочного института. В связь направлялись студенты-физики, в артиллерию - математики и т.д.»8.

Упоминание о том, как проходила запись в дивизию, можно встретить в мемуарах доктора физико-математических наук, заслуженного профессора Московского университета Горимира Горимировича Чёрного (в 1941 г. - студента механико-математического факультета МГУ): «...мы вернулись в успевший опустеть университет. Не встретив никого, поднялись на "голубятню" - маленькую получердачную комнатку с отдельной лестницей к ней с внутренней балюстрады здания и выходящим на балюстраду квадратным окошечком. Там обитало комсомольское бюро факультета 9 . Дежурный в бюро поведал нам, что студентов отправили под Смоленск "на окопы" - строительство оборонительных сооружений. А на вопрос, как нам быть дальше, сообщил, что в Москве началась запись в народное ополчение можете направиться туда. Ближайший к университету пункт записи - напротив зоопарка у бани <...> Мы с моим товарищем по учебной группе Игорем Степановым отправляемся к бане. Рядом с крыльцом перед входом в баню на тротуаре - небольшой стол, вокруг толпятся люди. За столом сидят трое. Перед средним развернута "амбарная" книга, в нее он вписывает добровольцев. Когда подошла наша очередь, окидывает нас взглядом, задает вопрос:

- Вы откуда?

- Из университета.
- Факультет?

- Механико-математический.

- Вот хорошо, пойдете в артиллеристы. Располагайтесь в доме напротив, - указывает рукой на пятиэтажное здание в глубине двора по соседству со стеной зоопарка.

Переходим улицу, входим во двор. Там прогуливаются три-четыре десятка человек. У двери дома столик, за ним человек в военной форме тоже заносит подходящих к нему в список, записывает и нас. Теперь мы с Игорем - бойцы артиллерийского полка 8-й Краснопресненской дивизии народного ополчения»10.

В ряды дивизии вступили также рабочие «Трехгорной мануфактуры», завода «Пролетарский труд" и других московских предприятий, а также работники фабрик и заводов Подмосковья - Воскресенского, Клинского, Коломенского, Можайского, Ногинского, Орехово-Зуевского районов. В 8-ю ДНО записалось более двухсот человек из Московской консерватории, а также из Государственного института театрального искусства, Театра Революцииㄹ, Юридического и Геологоразведочного институтов, Союза советских писателей, составивших т.н. «писательскую роту» и др.12 Так, в ряды ополчения вступили: писатель Александр Бек, актер Театра Революции, будущий драматург Виктор Розов, писатель Степан Злобин, сооснователь журнала «Огонек», писатель Ефим Зозуля, писатель Эммануил Казакевич, поэт Сергей Островой и др. Всего к 8 июля 1941 г. в 8-й ДНО насчитывалось 5334 человека13.

Известны многочисленные случаи, когда в дивизию попадали добровольцы, по некоторым критериям (возрасту, состоянию здоровья и др.) не подлежавшие мобилизации в народное ополчение. Так, весной 2016 г. поисковым отрядом «Вымпел - поиск МГУ» недалеко от деревни Уварово Ельнинского района Смоленской области, где в октябре 1941 г. сражалась 8-я дивизия, были обнаружены останки красноармейца. 


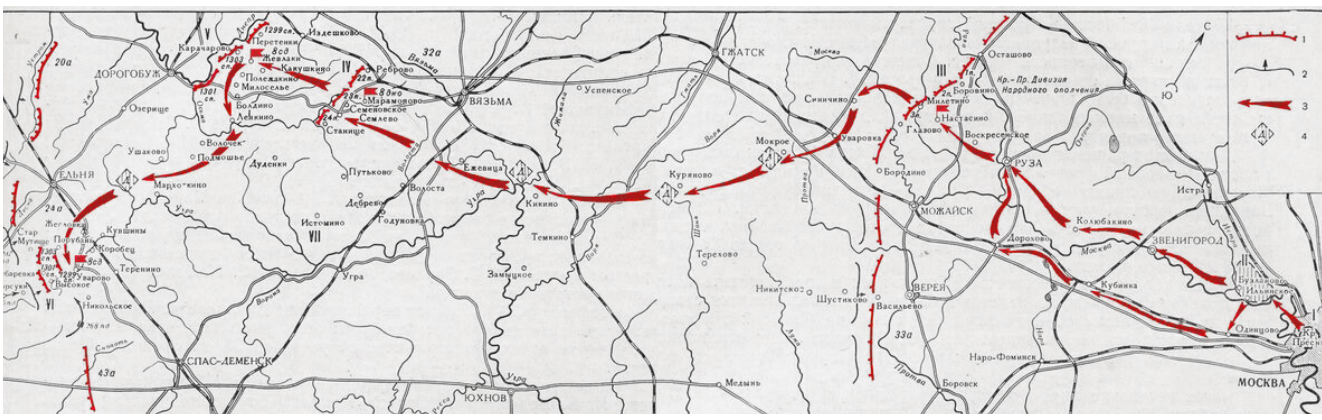

Схема движения 8-й дивизии народного ополчения

Источник: Московский университет в Великой Отечественной войне (с. 138-139)

Найденный при нем личный медальон принадлежал командиру пулеметного расчета Виктору Васильевичу Шиманову, которому на момент гибели было полных 16 лет14. О другом случае упоминает в своих мемуарах Виктор Розов: «Когда нас, ополченцев Красной Пресни, выстроили во дворе школы на 2-й Звенигородской улице и командир отчеканил: “Кто имеет освобождение от воинской повинности или болен, шаг вперед!" - ни один человек не сделал этого шага. Напротив, стоявший рядом со мной студент МГУ быстро снял свои сильные очки и спрятал их в карман»15.

Уже 9-10 июля части дивизии выдвинулись из города в западном направлении 16 . Ветераны 8-й ДНО вспоминали позднее: «Уходили из Москвы в своей одежде, обмундирование получали в пути, на привалах, так же как и оружие. Часть ополченцев отправилась прямо из университета <...> в походе проходили строевую подготовку, изучали оружие, боевые уставы, знакомились с основами военной техники»17. Дивизия участвовала в сооружении Можайской линии обороны, в начале августа части 8-й ДНО сосредоточились западнее, на Ржевско-Вяземской линии обороны ${ }^{18}$. В начале сентября она заняла оборонительный рубеж на Днепре, северо-восточнее города Дорогобуж Смоленской области ${ }^{19}$. После этого бойцы и командиры 8-й дивизии приступили к тщательной подготовке линии обороны: «Части и подразделения дивизии оборудовали ротные опорные пункты, рыли противотанковые рвы, сооружали противопехотные и противотанковые препятствия. Саперы минировали местность. Артиллеристы отрабатывали приемы ведения заградительного огня. Были составлены стрелковые карточки на каждый пулемет и планшеты управления огнем каждой батареи, установлены направления контратак, отсечные линии на случай прорыва врага на левый берег»20. Однако оборонять подготовленные рубежи краснопресненцам не пришлось.

«К тому времени уже не мы к фронту, а он к нам подошел вплотную, - вспоминал позднее боец дивизии К. Софин. Со стороны Дорогобужа все чаще слышалось глухое, как отдаленный гром, грохотание, по ночам горизонт высвечивался зарницами пожаров, а в тыл тянулись усталые и молчаливые бойцы, пыльные машины и обозные фигуры. Чувствовалось, что ждать нам осталось недолго»21.

Действительно, 2 октября 1941 г. был отдан приказ о передислокации 8-й дивизии южнее, в район Ельни, что было связано с резким ухудшением ситуации на фронте22. Утром 4 октября части 8-й дивизии вступили в бой с 15-й пехотной дивизией вермахта, получившей опыт в европейской военной кампании. «Обстановка для частей дивизии 
складывалась крайне неблагоприятно, т.к. они не успели завершить перегруппировку и занять намеченные рубежи обороны»23. К этому времени в ее рядах числилось около 7,5 тыс. человек. 8-й дивизии противостояли соединения немецкого 20-го армейского корпуса, насчитывавшего около 45 тыс. человек, наступавшие при поддержке танков, артиллерии и авиации 24. О потерях, понесенных дивизией, свидетельствует тот факт, что уже в первый день боев было ранено около 1200 красноармейцев ${ }^{25}$. Задержав продвижение врага, 5 октября 8-я дивизия потеряла более половины личного состава, а к вечеру следующего дня фактически прекратила свое существование.

Почти восемьдесят лет спустя после тех трагических событий оценить общее количество погибших бойцов и командиров 8-й дивизии крайне сложно. Известно, что многие красноармейцы пополнили ряды партизанских отрядов или, выйдя из окружения, продолжали воевать в других воинских формированиях, часть - оказалась в плену. По самым примерным оценкам И.Н. Находкина, в районе боев 8-й дивизии в радиусе нескольких километров может находиться около четырех тысяч красноармейцев, чья судьба по сей день неизвестна26.

\section{«Помнить действием»}

В СССР поисковое движение было официально признано лишь спустя 43 года после окончания войны - весной 1988 г., когда на Первом Всесоюзном сборе поисковиков было принято решение о создании Всесоюзного координационного совета поисковых отрядов под председательством Ю.М. Иконникова27. Вплоть до этого времени de jure такого движения не существовало. Фактически же десятки лет после окончания войны поиск пропавших без вести красноармейцев не относился к числу значимых, с точки зрения государства, задач: «Реальная поисковая работа велась только отдельными энтузиастами или группами энтузиастов при бездействии государственных органов» 28 . Что же касается возвращения имен пропавших без вести краснопресненцев, то фактически официальные, систематические и комплексные мероприятия, включающие в себя полный цикл работ (архивные изыскания, изучение истории народного ополчения, материально-правовую организацию экспедиций, собственно археологические раскопки, торжественные захоронения найденных красноармейцев, медиапокрытие проводимых мероприятий и др.), стали проводиться лишь в 2000 гг. Серьезным шагом в организации таких работ можно считать первую экспедицию поискового отряда «Вымпел - поиск» в 2014 г. (руководитель - И.Н. Находкин, заместитель - П.А. Григорьев). Год спустя при поддержке ректора МГУ имени М.В. Ломоносова академика В.А. Садовничего стало возможным создание молодежного подразделения организации «Вымпел - поиск МГУ», со временем объединившего студентов многих факультетов Московского государственного университета - исторического, факультета журналистики, химического, психологии, почвоведения, фундаментальной медицины, юридического, философского, географического, физического, факультета вычислительной математики и кибернетики, политологии, государственного управления, а также студентов Института стран Азии и Африки (ИСАА), Высшей школы телевидения и Высшей школы современных социальных наук.

Археологические работы в районе боев 8-й дивизии имеют свою специфику. Прежде всего, поиски затруднены в связи с отсутствием четко выраженного рубежа обороны, т.к. 4 октября 1941 г. части дивизии вступали в бой практически с марша29. Кроме того, за время, прошедшее 


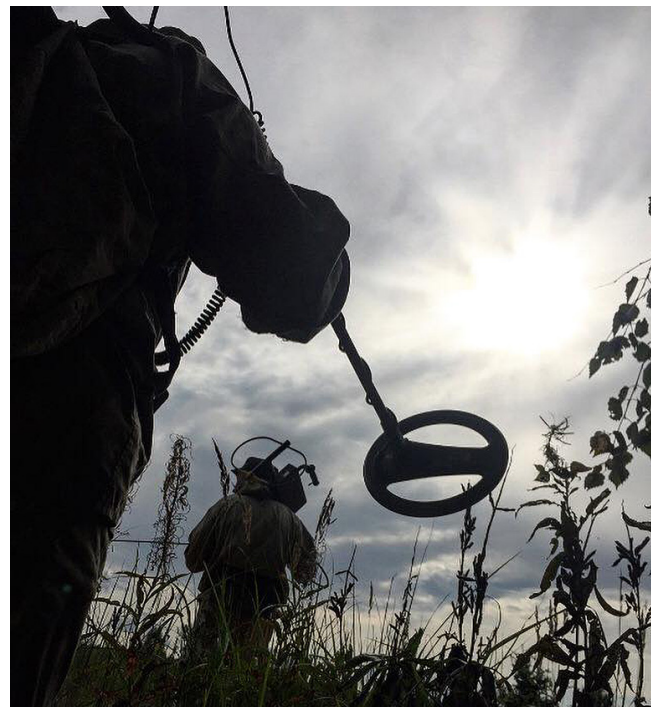

Поисковые работы.

Ельнинский р-н, д. Уварово, 2018 г.

с момента окончания войны, несколько изменился ландшафт, исчезли некоторые известные по источникам населенные пункты (деревня Лозино и др.). Следует также отметить, что сегодня в распоряжении археологов имеется весьма ограниченный круг письменных (официальные документы, воспоминания) и устных (свидетельства очевидцев, их родственников или знакомых) источников, позволяющих локализовать поиски дивизии, история которой была трагически недолгой с июля по октябрь 1941 г.

Выезды экспедиции проходят дважды в год: в конце апреля - начале мая, а также во второй половине августа. На основе имеющихся источников руководством отряда определяется примерная область поиска, которая затем исследуется с помощью металлоискателей и щупов - длинных металлических стержней, заостренных с одной стороны. С помощью такого приспособления опытный археолог может определить, что находится под землей - металлический предмет, фрагмент дерева или кость.
Цель поисков заключается в том, чтобы найти останки бойца, а также небольшую капсулу с бумажным вкладышем, содержащим данные красноармейца - его личный медальон. «Я помню, как нашли первый солдатский медальон, - вспоминает об одном из таких эпизодов участник поискового отряда Иван Корякин. - Еще сильнее меня поразило, когда вечером его аккуратно вскрывали в нашем лагере. И самое важное - владельцем медальона оказался 17-летний юноша. На следующий день мы нашли 16-летнего юношу. Это произвело на меня огромное впечатление. Потому что можно сколько угодно слушать о том, что в войне принимали участие совсем дети, но это несравнимо с тем, когда ты лично в этом убеждаешься» 30 .

Если медальон получается прочесть (сразу или позднее реконструировать сохранившиеся записи), начинается следующий этап работы, связанный с поиском членов семьи бойца. При самом удачном стечении обстоятельств удается найти близких родственников. Так, несколько лет назад в Воскресенске были найдены три дочери некогда пропавшего без вести под Ельней красноармейца, которые в 1941 г. провожали его на фронт. Такой поиск может занимать длительное время, но иногда результат не заставляет себя ждать. В практике поискового отряда известен случай, когда племянница обнаруженного во время археологических работ под Ельней лейтенанта была найдена через социальную сеть «Одноклассники»31.

Всего за время поисковых работ в Ельнинском районе были обнаружены останки примерно восьмидесяти красноармейцев. Благодаря сохранившимся в некоторых случаях личным медальонам удалось идентифицировать имена тридцати из них, что является редкой удачей. Самой результативной оказалась восьмая экспедиция «Вымпел - поиск МГУ» (весна 2018 г.), в ходе которой были подняты останки тридцати пяти красноармейцев. Кроме того, результаты 


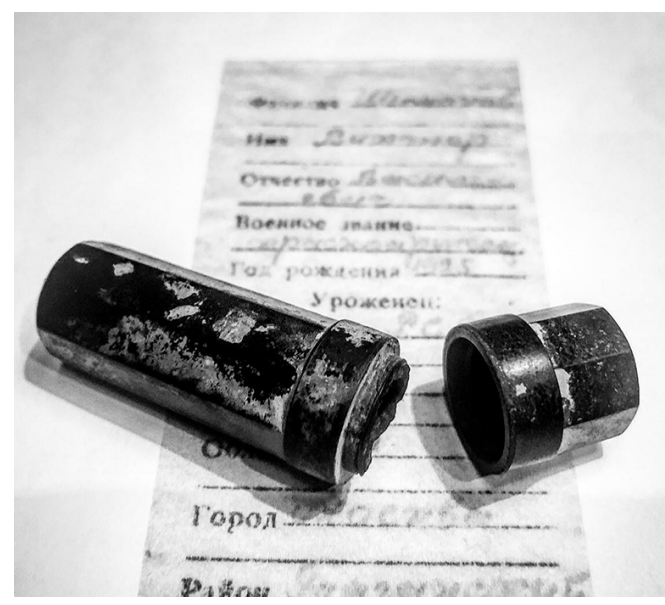

Солдатский медальон В.В. Шиманова

этого выезда позволили прорабатывать версию о возможной связи найденных останков и артефактов с малоизвестным эпизодом - гибелью санитарного обоза, двигавшегося из деревни Уварово в сторону деревни Каменец.

Некоторые найденные в ходе экспедиций артефакты (заколка, стеклянные колбы и пробирки, предположительно принадлежавшие медсестрам 8-й дивизии, фрагменты пролежавшей в земле газеты, личные вещи бойцов - монеты, химический карандаш, алюминиевый котелок с процарапанной фамилией «Маскаев», стеклянная фляга и проч.) стали частью посвященной истории 8-й дивизии народного ополчения постоянной экспозиции, открывшейся 22 сентября 2019 г. на факультете журналистики МГУ при поддержке декана факультета, профессора Е.Л. Вартановой. Так сложилось, что эта экспозиция теперь находится рядом

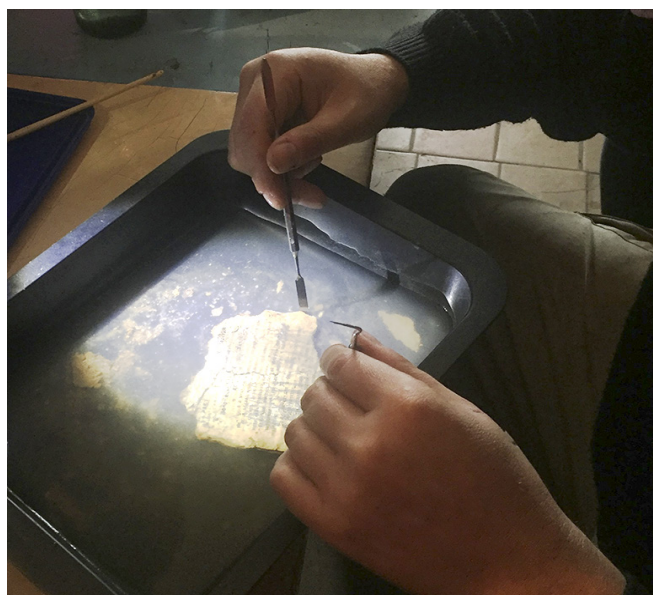

Фрагмент инструкции по стрелковому делу, найденной в д. Зубово Ельнинского р-на, 2017 г.

с бывшей Коммунистической аудиторией, в стенах которой в предвоенные годы слушали лекции студенты Московского университета - будущие ополченцы 8-й дивизии ${ }^{32}$. Кроме того, постоянная экспозиция, посвященная истории 8-й ДНО, открылась 10 марта 2020 г. в Музее истории МГузз.

Несмотря на значительную работу, проделанную историками и археологами, можно говорить о том, что история дивизии еще не написана. Не исключено, что она может быть значительно дополнена за счет привлечения новых архивных данных (из российских или немецких архивов), а также благодаря новым уникальным артефактам, найденным в ходе поисковых экспедиций, прежде всего - солдатским медальонам, т.к. самым важным этапом создания такой истории является возращение имен бойцов и командиров дивизии, пропавших без вести в октябре 1941 г.

\section{Примечания}

${ }^{1}$ Москва - фронту. 1941-1945: сб. документов и материалов / отв. ред. С.М. Кляцкин. М.: Наука, 1966. С. 120-121; Ополчение на защите Москвы. Документы и материалы о формировании и боевых действиях Московского народного ополчения 
в июле 1941 -январе 1942 г. / под ред. А.М. Петрова; сост. Л.С. Беляева, В.И. Бушков, И.И. Кудрявцев. М.: Моск. рабочий, 1978. С. 31.

2 С 23 августа 1941 г. - 8-я стрелковая Краснопресненского района дивизия, с 26 сентября - 8-я стрелковая дивизия. Командовал дивизией комбриг Д.П. Скрыпников.

3 Ополчение на защите Москвы. С. 59. (Из справки о боевом пути 8-й дивизии народного ополчения - о формировании дивизии в июле 1941 г. Апрель 1966 г. Документ составлен бюро ветеранов 8-й ДНО.)

4 Московский университет в Великой Отечественной войне. М.: Изд-во Моск. унта, 1975. С. 135.

5 Московский университет в Великой Отечественной войне. 2-е изд., перераб. и доп. М.: Изд-во Моск. ун-та, 1985. С. 141; Московский университет в Великой Отечественной войне. 3-е изд., перераб. и доп. М.: Изд-во Моск. ун-та, 2015. С. 213.

${ }^{6}$ См., напр.: Слухай И.А. Московское народное ополчение в годы Великой Отечественной войны. М.: Патриот, 2013. С. 149.

7 Интервью с И.Н. Находкиным. (Архив автора. 03.08.2020.)

8 Ополчение на защите Москвы. С. 75. (Из отчетов отделов райкомов партии г. Москвы МГК ВКП(б) о формировании дивизий народного ополчения в июле 1941 г. Сентябрь, 1942 г. Отчет Краснопресненского РК ВКП(б). 21 сентября 1942 г.)

9 Вероятно, речь идет об 329 аудитории, располагающейся в здании факультета журналистики МГУ имени М.В. Ломоносова (ул. Моховая, 9).

10 Цит. по: Московский университет в Великой Отечественной войне. 3-е изд., перераб. и доп. М.: Изд-во Моск. ун-та, 2015. С. 572.

11 Ныне - Московский академический театр имени Владимира Маяковского.

12 Ополчение на защите Москвы. С. 59-60.

13 Москва - фронту. С. 123. (Сводная таблица о боевом и численном составе дивизий народного ополчения г. Москвы к моменту их ухода на подмосковные рубежи. 8-16 июля 1941 г.)

14 На факультете журналистики МГУ в экспозиции, посвященной 8-й дивизии народного ополчения, хранится копия обнаруженного во время археологических работ весной 2016 г. вкладыша на имя Шиманова Виктор Васильевича, 16-летнего командира пулеметного расчета, Подлинник вкладыша был передан его родственникам.

Подр. об этом см.: «Вымпел - поиск МГУ» - мультимедийный проект кафедры фотожурналистики и технологий СМИ факультета журналистики МГУ имени М.B. Ломоносова, посвященный 75-летию Победы. Режим доступа: http://poisk-msu.ru/9/ ?fbclid=IwAR16MmlpTPz2CFpAe5BYHIzbds4aC9XbmpC63T5VG2luyYqaSS7fLZLwjzY (дата обращения: 03.08.2020).

15 Розов В.С. В московском ополчении. М.: Родина, 2020. С. 30.

16 Домницкий Н.Г. 8-я Краснопресненская. Боевой путь (Историческая справка) // Пошеманский Ю.М. Солдаты Красной Пресни. М.: Моск. рабочий, 1984. С. 7.

17 Ополчение на защите Москвы. С. 185-186.

18 К этому времени она вошла в состав 32-й армии, непосредственно перед началом боев под Ельней она была переподчинена 24-й армии. 
19 Московский университет в Великой Отечественной войне. 3-е изд., перераб. и доп. М.: Изд-во Моск. ун-та, 2015. С. 216-217.

20 Домницкий Н.Г. Указ. соч. С. 10.

21 Пошеманский Ю.М. Солдаты Красной Пресни. М.: Моск. рабочий, 1984. С. 37.

22 За несколько дней до этого германское командование приступило к реализации оперативного плана по захвату Москвы «Тайфун».

23 Каримов В.И. Они отстояли Москву. Летопись народного ополчения Москвы. М.: Планета, 2016. С. 240.

24 «Вымпел - поиск МГУ» - мультимедийный проект кафедры фотожурналистики и технологий СМИ факультета журналистики МГУ имени М.В. Ломоносова, посвященный 75-летию Победы. Режим доступа: http://poisk-msu.ru/9/?fbclid=IwAR16 MmlpTPz2CFpAe5BYHIzbds4aC9XbmpC63T5VG2luyYqaSS7fLZLwjzY (дата обращения: 05.08.2020).

25 Ополчение на защите Москвы. С. 187.

26 Интервью с И.Н. Находкиным. (Архив автора. 03.08.2020.)

27 Нагаев И.М. Как начинался поиск в России // Методические рекомендации по военной археологии (по поисковой работе на местах боев Великой Отечественной войны). М.: Азбука, 2009. С. 34.

28 Петров В.Н. К истории вопроса (о проблеме незахороненных в годы Великой Отечественной войны останков погибших и "пропавших без вести» солдат и офицеров и молодежной политике) // Методические рекомендации по военной археологии (по поисковой работе на местах боев Великой Отечественной войны). М.: Азбука, 2009. С. 26.

29 Интервью с И.Н. Находкиным. (Архив автора. 03.08.2020.)

30 «Вымпел - поиск МГУ» - мультимедийный проект кафедры фотожурналистики и технологий СМИ факультета журналистики МГУ имени М.В. Ломоносова, посвященный 75-летию Победы. Режим доступа: http://poisk-msu.ru/12/?fbclid =IwAR16MmlpTPz2CFpAe5BYHIzbds4aC9XbmpC63T5VG2luyYqaSS7fLZLwjzY (дата обращения: 05.08.2020).

31 Там же (дата обращения: 08.08.2020).

32 Ныне - лекционная аудитория 232.

зз Экспозиция была подготовлена выпускниками Мгу, участниками отряда «Вымпел - поиск МГУ» Е.И. Нагорной и Н.С. Лазюком. 